Phys. Comm. 3(1)(2019) 41-46
Physics Communication
UNttp://journal.unnes.ac.id/nju/index.php/pc

\title{
Descriptive Analysis of Student's Self Efficacy in The Discovery Learning Processes
}

\author{
Husna Noor Mufida ${ }^{\bowtie}$, Suharto Linuwih, Sugianto \\ Pascasrjana, Universitas Negeri Semarang, Indonesia
}

\begin{abstract}
Article Info
Abstract

Article History:

This research aims to describe the state of self efficacy on the application of learning discovery learning Submitted: July, 162018

Accepted:

October, 262018

Published:

October, 262018 model on harmonic vibration topic. In addition to reveal the factors that influence the increase or decrease of students' self efficacy with the application of discovery learning model. This research is a qualitative descriptive analysis research. Discovery learning model is implemented in 38 students class X MIPA 2 of SMA 1 Bae Kudus. Data collection was done by giving questionnaires, observation, and interview. Questionnaire of student's self efficacy also has been given to determine the condition of self efficacy of students before and after the learning process implemented. The results showed that the initial self efficacy condition of students who had low initial increase although not significant. The condition of early efficacy of students before the learning process determines the level of student success in the learning process. Analysis of the first time self efficacy of students with the low category can be used as an anticipation or prevent the final learning outcomes of students do not become low.
\end{abstract}

Keywords:

Self efficacy, Discovery

learning, Harmonic

vibration. 


\section{INTRODUCTION}

Globalization demands the development of knowledge and technology, so that not only intelligence is required but must be balanced with motivation. Motivation not only arises when a person's intelligence is high, but also when a person is confident in his ability to do something. The belief that one is capable to do something for a certain purpose is called self efficacy.

In terms oif education, the existence of self efficacy is very important. Strong self efficacy will encourage students to stay ahead in achieving their goals. Self efficacy is not something that exists by itself, but can be obtained, altered, enhanced, through several factors. Bandura (2010) generally classifies factors that affect self efficacy: a) Mastery Experiences, b) Vicarious Experiences, c) Social Persuation, and d) Physiological and emotional states.

Students who have confidence that they are able to achieve more success than their ability, are the student will achieve higher results. Conversely, there are students who have high ability but because they are lazy and underestimate the tasks from the teachers so that learning achievement is below the average group, this is called underachiever (Sulthon, 2014). In addition, despite the failure, students with high self efficacy will be able to encourage students not to give up easily. Daniel Cervone and Lawrence A. Pervin (2012) argue that self efficacy affects how people overcome disappointment and pressure in achieving their life goals. Students with high self efficacy are certainly more able to accept the disappointment of failure and try to get up to reach it again. Bandura believes that self efficacy is an important factor for an outstanding or underachieving student (Santrock, 2007).

There have been several studies that have attempted to improve students' self efficacy in schools. One of his efforts is to use effective, innovative and funny learning models. Wibowo (2016) implemented guided inquiry learning model to improve students' self efficacy. His research succeeded in improving the students' self efficacy from the "high" category to the "very high" category. Liufeto (2012) has also implemented peer tutor learning model or peer guidance to improve students' self efficacy. The learning model proved to increase self efficacy more than $60 \%$ of students in the sample. The Jigsaw II learning model has also been successfully done to improve students' self efficacy when compared to the lecture learning model (Wahyu, 2015). Another learning model that influences and can improve students' self efficacy is Problem Based Instruction (Huda et al, 2015).

Discovery learning is a learning model developed based on the view of constructivism. This model emphasizes the importance of understanding structures or important ideas to a discipline, through active involvement of students in the learning process. Bruner argues that learning to discover / discovery refers to the mastery of knowledge for oneself (Mawaddah dkk, 2015). Discovery learning model is a learning theory that is defined as a learning process that occurs when students are not presented with lessons in final form, but it is expected that students organize themselves.

Self efficacy theory comes from Social Learning Theory of a researcher named Bandura. Bandura states that self efficacy or self efficacy is the individual's perception of his / her ability to perform the expected action. Self efficacy beliefs influence the choice of action to be taken, the amount of effort and resilience when faced with obstacles or difficulties. Individuals with high self efficacy choose to do more business and never give up (Bednall et al, 2011)

Bandura mentions that there are three dimensions of self efficacy (Mustaqim, 2008), namely: (1) Generality; This dimension of generality is related to the breadth and variety of task fields. This dimension is concerned with the breadth and diversity of areas of task facing the individual. (2) Level / Magnitude; This level dimension is related to the difficulty level of the task at hand. If the tasks assigned to the individual are structured according to the degree of difficulty, then individual self efficacy differences may be limited to simple, medium or high tasks. Individuals will perform actions that are perceived to be capable of performing and will be tasks that are thought to be beyond the limits of their capabilities. The level aspect is the aspect that has the greatest influence in self 
efficacy variables compared to the other two aspects, but the strength and generality aspect also affect the overall self efficacy although not the magnitude (Pujiati, 2010). (3) Strength; This dimension of strength is related to the degree of variation in strength, ie the dimension associated with one's self-beliefs about the ability to achieve success or optimal results, even though the task has not been confronted with it. The lower level of self efficacy is easily shaken by the debilitating experiences, whereas individuals with strong self efficacy will be diligent in enhancing their efforts despite the debilitating experience.

\section{METHOD}

This research was conducted at SMA 1 Bae Kudus in the academic year 2016/2017. SMA 1 Bae Kudus is one of the public schools in Kudus District, Central Java Province. Researchers choose SMA 1 Bae Kudus as a research place because SMA 1 Bae Kudus is one of the high school in holy that is good in the academic field every year. This research was conducted in class X IPA 2 in semester 2 (even) Harmonic Vibration material with 5 times meeting time allocation 2x45minutes and $3 \times 45$ minutes.

This research focused on the analysis of self efficacy of students in the process of physics learning on Harmonic Vibration material by using discovery learning learning model. The data source of this research is determined by purposive sampling, which is selected based on certain considerations and objectives, in order to obtain the accuracy and adequacy of the required information (Sugiyono, 2014). Students who serve as the main data source in the research are the students of SMA 1 Bae Kudus class X IPA 2 2nd semester of Lesson Year 2016/2017 and has been grouped each 3 people, so that formed 10 groups. Data collection techniques used in this research are as follows: (a) participatory observation, (b) interview, and (c) documentation.

\section{RESULT AND DISCUSSION}

In this study has been done learning discovery learning process to determine the condition of self efficacy of students before and after the learning process. Learning discovery learning in self efficacy research using sample of students of class X MIPA 1 SMA 1 Bae Kudus. Instruments for the efficacy analysis were performed through several stages including initial analysis of student efficacy, efficacy analysis of students in the learning process, student efficacy analysis after learning. Research instruments in the form of questionnaires have been validated by inquiry experts, material experts, and small groups of learners. The average overall assessment of the questionnaire developed very good category. Thus, this questionnaire is feasible to be used for data retrieval process.

The Learning steps in this research consists of five meetings. The first meeting was used to get acquainted with students and fill out an initial questionnaire on students' self-efficacy before participating in the learning of harmonic vibration material with the Discovery Learning method. The next activity is used to pretest harmonic vibration material. The second meeting was used for learning to determine single spring constants and total spring constants of series and parallel spring arrangements. The obstacle found in this first meeting was that students could not share their tasks with members of one group. The third meeting analyzed the equations of deviation, speed and acceleration of harmonic vibration. Students experience difficulties in understanding and decreasing deviation, speed and acceleration equations.

The fourth meeting identifies phase, phase, and phase difference angles and determines the period value and frequency of harmonic vibrations in the pendulum and spring swings. This fourth meeting students begin to divide tasks with members of one group. Students have little difficulty in understanding sinusoidal graphs and difficulties in formulating phases mathematically. The researcher randomly appoints one group to present the results of the discussion and the other group can respond. The fifth meeting explained the concept of energy and the law of conservation of energy in simple harmonic motion and carried out posttest and filled out the final questionnaire on student self-efficacy.

The data result are quantitative data and qualitative data. Quantitative data is obtained from pretest and posttest of harmonic vibration material. Qualitative data in this study were obtained from 
the results of questionnaires and student observation sheets that have been observed by three observers. The learning results of the self efficacy, cognitive, and observational tests of learners before and after they undergo a discovery learning process are presented in Table 1.

Table 1. Statement and results of student self efficacy questionnaire,

\begin{tabular}{|c|c|c|c|c|}
\hline Question & Statement & Score & Amount & Percentage \\
\hline \multirow[t]{4}{*}{1} & \multirow{4}{*}{$\begin{array}{l}\text { If suddenly the teacher holds a test, I try to } \\
\text { do it as well as possible }\end{array}$} & 4 & 10 students & $26 \%$ \\
\hline & & 3 & 15 students & $39 \%$ \\
\hline & & 2 & 10 students & $26 \%$ \\
\hline & & 1 & 3 students & $8 \%$ \\
\hline \multirow[t]{4}{*}{2} & \multirow{4}{*}{$\begin{array}{l}\text { I tried working on test questions with } \\
\text { confidence }\end{array}$} & 4 & 6 students & $16 \%$ \\
\hline & & 3 & 23 students & $61 \%$ \\
\hline & & 2 & 8 students & $21 \%$ \\
\hline & & 1 & 1 students & $3 \%$ \\
\hline \multirow[t]{4}{*}{3} & \multirow{4}{*}{$\begin{array}{l}\text { If I find it difficult to answer the test } \\
\text { questions, I will see a friend's answer }\end{array}$} & 4 & 2 students & $5 \%$ \\
\hline & & 3 & 19 students & $50 \%$ \\
\hline & & 2 & 12 students & $32 \%$ \\
\hline & & 1 & 5 students & $13 \%$ \\
\hline
\end{tabular}

The initial and final scores of students' self efficacy were compared and the overall results showed that a total of 23 students experienced an increase in self efficacy, 4 students had a self efficacy score, and 11 students experienced a decrease in self efficacy scores. Of the 23 students who received an overall self efficacy score, there were only seven students whose generality, level, and strength aspects experienced an increase in all three aspects. there were 17 students who had a total self efficacy score increasing, but the increase was only in two aspects. There were also 11 students who had a total self efficacy score decreased, but there was only one student where in all three aspects (generality, level, and strength) decreased. The table for increasing student self efficacy in each aspect is shown in Table 2.

Table 2. Improved aspects of student self efficacy and value of learning outcomes.

\begin{tabular}{|c|c|c|c|c|c|}
\hline \multirow{2}{*}{ Student } & \multicolumn{3}{|c|}{ Enhancement } & \multirow{2}{*}{ Total Score } & \multirow{2}{*}{$\begin{array}{c}\text { Learning } \\
\text { Result }\end{array}$} \\
\hline & Generality & Level & Strength & & \\
\hline $\mathrm{R} 1$ & + & + & + & + & + \\
\hline $\mathrm{R} 2$ & + & + & + & + & + \\
\hline R9 & $=$ & + & $=$ & + & + \\
\hline R17 & - & + & + & + & + \\
\hline R23 & - & - & - & - & - \\
\hline R24 & - & + & $=$ & - & - \\
\hline R27 & + & + & - & - & + \\
\hline
\end{tabular}

Inf: (+) increase; (=) Constant; (-) decrease

In Discovery Learning learning conducted in students' self efficacy research, researchers did not take specific actions to improve students' self efficacy. The research only aims to explore more information about the initial efficacy of students and the final efficacy of students after discovery learning. Student self efficacy research data obtained from the results of questionnaires, observations, and interviews are presented in detail with qualitative methods. Self efficacy relates to the belief that the self has the ability to do the expected action. In harmony with Wulansari (2001) research self 
efficacy refers to the individual's belief that he is able to carry out a desired task. Self efficacy can be developed within students. This research is consistent with Bandura's opinion in Alwisol (2004) that self efficacy can be obtained, changed, improved or derived from one or four sources, namely the experience of mastering something (performance accomplishment), vicarious experience, social persuasion (social persuation, and emotional / physiological states.

The results showed a very significant positive relationship between self efficacy and learning outcomes. That is, the higher the self efficacy of students, the higher the student's learning outcomes and vice versa. Learning outcomes are related to learning motivation. These results are in accordance with the opinion (Bandura, 2010) that someone who has high self efficacy will have a higher learning motivation, the higher the self efficacy of a person, the higher the motivation to learn. This is reflected by the amount of effort done and perseverance in overcoming the obstacles. He will continue to do his tasks and not give up easily and endure when encountering difficulties. People who have high self efficacy will try harder in overcoming the obstacles.

From the respondents' answers, it was known that self efficacy was obtained from various sources, including from within the respondent himself, namely the ability to complete various tasks and from the experiences of others around the respondents. Most students are motivated by people around students. Teachers who provide motivation to students to succeed also become one of the stimuli from outside the respondent.

Efficacy factors are also influenced by the family environment. The family environment is the first and foremost educational institution, where most of the children's decisions will be influenced by the family's self-efficacy in physics learning is also influenced by the school environment. Children tend to imitate the habits of the majority of the surrounding environment. In interview questions related to difficult homework assignments, some students stated "I did not do homework, because my friend did not work so it was safe, even though he was punished there was a friend"

\section{CONCLUSION}

This study has produced a description of the efficacy of students before and after the physics learning process implemented. Student self efficacy affects student learning outcomes, students with high efficacy tend to get high learning outcomes at the end of the learning process, while students with low efficacy tend to get a low learning as well. The self efficacy description before the learning begin can be used as an anticipation to the students who have low efficacy so that their learning result are not low.

\section{REFERENCES}

Bandura, A. 2006. Guide for Constructing Self-Effiacy Scales. USA: Age Publishing.

Bandura,A. 2010. Perceived Self-Efficacy in Cognitive Development and Functioning, Educational Psychologist, 28(2): 117-148.

Bednall, T. C., \& Kehoe, E. J. 2011. Effects of Self-Regulatory Instructional Aids on Self-Directed Study, Instrumental Scince, 39(5): 205-226.

Dalyono. 2005. Psikologi Pendidikan. Jakarta: Rineka Cipta.

Damayanti, H., Sarwi, B. Astuti. 2018. A Study of Student's Misconception on Light Material and How to Reduce it Using LKS-Assisted PBL at Islamic Junior High School (SMP IT) Bina Amal Semarang. Physics Communication. 2 (2):103-111.

Dewi, A.R.C, Susilo, N. M. Dharma Putra. 2018. Analysis of Student Practical using Logger Pro to Improve Graphic Representation of Harmonic Oscillation Material. Physics Communication. 2 (2):112-121.

Huda, M.S., Surbakti, A., Marpaung, R.R. 2015. Pengaruh Model Pembelajaran Probleem Based Instruction terhadap Self Efficacy dan Hasil Belajar. Jurnal Bioterdidik: Wahana Ekspresi Ilmiah, 3(9): 105-110.

Mustaqim. 2008. Psikologi Pendidikan. Semarang: Pustaka Belajar.

Mawaddah, N.E. 2015. Model Pembelajaran Discovery Learning dengan Pendekatan Metakognitif untuk Meningkatkan Metakognisi dan Kemampuan Berpikir Kreatif Matematis. Unnes Journal of Mathematics Education Research. 4(1) 17-25.

Ni'mah, K. 2014. Hubungan antara dukungan sosial dan self efficacy dalam menyelesaikan skripsi. Indonesian Journal of Guidance and Counseling: Theory and Application, 3(1). 
Nurhayati, I., Wardani, D. K., Totalia S.A. 2015. Upaya Meningkatkan Academic Self Efficay dan Hasil Belajar Siswa Melalui Model Pembelajaran Discovery Learning di SMK Negeri 3 Surakarta. Jurnal Pendidikan Ekonomi dan Bisnis, 1(1): 1-7.

Santrock, J. W. 2007. Psikologi Pendidikan (edisi kedua) (Penerjemah Tri Wibowo, S. E.), Jakarta: Kencana.

Singh, B., \& Udainiya, R. 2009. Self Efficacy and Well-Being of Adolescents. Journal of The Indian Academy of Applied Psychology, 35(2): 227-232.

Wahyu, W. 2015. Peningkatan Efikasi Peserta Didik dalam Pembelajaran Kimia melalui Teknik Jigsaw II. Prosiding Simposium Nasional Inovasi dan Pembelajaran Sains. 4 (2) 577-580. 